\title{
MODULATION OF URETHRAL ALPHA-SYMPATHETIC BY PARASYMPATHETIC BEFORE AND FOLLOWING BETHANECHOL CHLORIDE INJECTION
}

\author{
HAYLTON J. SUAID, JEOVÁ N. ROCHA, ANTONIO C.P. MARTINS, ADAUTO J. COLOGNA, \\ SILVIO TUCCI JUNIOR
}

\author{
Section of Urodynamics, Division of Urology, Department of Surgery and Anatomy, \\ HCFMRP-USP, São Paulo, SP, Brazil
}

\begin{abstract}
Introduction and Objectives: Chagas' disease causes specific parasympathetic denervation and in its digestive clinic form promotes also functional alterations in bladder. Thus, the aim was to investigate the existence of balance between sympathetic and parasympathetic systems in lower urinary tract, as occurs in other organs. We verified the urethral closing pressure before and following parasympathetic stimulus.

Patients and Methods: For that, the urethral closure pressure was studied before and after the injection of $5 \mathrm{mg}$ of bethanechol chloride subcutaneously in 28 voluntary female patients, divided into 4 groups. The constitution of theses groups was: A) normal control $=6$ patients; B) Chagas' disease with positive serology only $=5$ patients; C) Chagas' disease with cardiac disease $=6$ patients, and D) Chagas' disease with digestive disease and vesical hyporeflexia $=11$ patients. Urethral profilometry was performed through perfusion urethral catheter with a $6.5 \mathrm{ml} / \mathrm{minute}$ flow and a traction rate of $5 \mathrm{~mm} /$ minute.

Results: Means and standard deviations for urethral closure pressure before bethanechol chloride were respectively: group $A=67.3 \pm 7.1$; group $B=69.2 \pm 7.4$; group $C=95.8 \pm 5.1$; group $\mathrm{D}=82.1 \pm 8.4$. After bethanechol chloride they were: group $\mathrm{A}=66.0 \pm 6.6$; group $\mathrm{B}=77.0 \pm 7.6$; group $\mathrm{C}=98.3 \pm 8.8$; group $\mathrm{D}=45.9 \pm 6.2$. The Kruskal Wallis statistical test did not show statistically significance difference between groups A, B, C. However, it was statistically significant between groups $\mathrm{C}$ and $\mathrm{D}$ with $\mathrm{p}=0.003$. Wilcoxon test showed $\mathrm{p}=0.001$, only for values in group $\mathrm{D}$ before and following bethanechol chloride.

Conclusions: Chagas' disease in its intestinal form seems to alter urethral function as well. Parasympathetic stimulation decreased urethral pressure, indicating potential modulation by the parasympathetic system over the sympathetic system.
\end{abstract}

Key words: urethra; sympathetic nervous system; parasympathetic nervous system; bethanechol; Chagas disease

Int Braz J Urol. 2003; 29: 162-5

\section{INTRODUCTION}

Chagas' disease, an endemic problem in Brazil, was largely studied concerning impairment of autonomic nervous system. The symptoms are a consequence of lesions produced in peripheral parasympathetic vegetative innervation (1), which involves mainly heart and large bowel, and the studies are focused on theses organs and on central nervous system.
There are few reports in literature concerning the impairment of genitourinary system. Thus, in 250 autopsies of patients with Chagas' disease, 2 cases of megabladder were found (2). The impairment of parasympathetic system neurons in inferior hypogastric ganglion was experimentally verified in rats (3). One of the major factors of these hypogastric ganglia is the presence of nitric oxide synthase (NOS) in postganglionic nerves. Nitric oxide (NO) 
promotes the relaxation of the smooth muscle fiber (4). Stimulation of lumbar afferent nerve roots promotes vesical contraction and urethral relaxation. The blockage of NOS produces inhibition of urethral relaxation (5). In relation to the bladder, anatomic study of vesical wall in animals with megabladder did not identify structural alterations (6). Functional study of bladder in patients with Chagas' disease was performed recently, where a drop in detrusor's pressure was found with increase of abdominal pressure during voiding and increase in voiding time (vesical contraction) (7). The association of these facts with lesion of juxtavesical ganglion could reflect in modulation of muscles contractions in bladder and urethra.

\section{Justification}

Considering the findings described above that patients with Chagas' disease, in its intestinal form, have impairment of vesical function and present also alterations in urethral closure pressure, it was questioned if there was or not a functional modulation between sympathetic and parasympathetic systems in lower urinary tract.

\section{Objective}

To verify the influence of lower urinary tract's parasympathetic system during modulation of urethral muscles' contraction.

\section{PATIENTS AND METHODS}

Twenty-two female volunteers were selected, with positive serology or with Chagas' disease in its cardiac form, or digestive form with hyporeflexive vesical dysfunction, and other 6 volunteers considered normal, whose ages ranged from 37 to 48.5 years. They were assigned in 6 normal women who constituted group A (control); 5 in group B (patients with positive serology without disease); 6 in group $\mathrm{C}$ (patients with Chagas' disease and cardiopathy) and 11 in group D (patients previously studied, with disease involving the digestive tract and vesical hyporeflexia), all of them were asymptomatic concerning the urinary tract.

\section{Urethral Profile}

The study was performed with a Life Tech Inc 1154 device, where urethral profile tracings were obtained. The methodology employed was perfusion with a continuous infusion pump and flow of $6.5 \mathrm{ml} /$ minute, and catheter mechanical traction with a speed of $5 \mathrm{~mm} /$ minute $(8,9)$. With this methodology, static profiles were done for determining closure pressures. Following, it was injected, subcutaneously in forearm, $5 \mathrm{mg}$ of bethanechol chloride. After a waiting period of 30 minutes, the static urethral profiles were repeated.

\section{Statistical Analysis}

It was performed through Kruskal-Wallis test for comparison between the 4 studied groups and through Wilcoxon nonparametric test for evaluating data within the same group.

\section{RESULTS}

Results are expressed in Table-1. Before administration of bethanechol chloride it can be observed that means and standard deviations of urethral closing pressure values were, respectively, for group A (normal control), $67.3 \pm 7.1 \mathrm{~cm}$ of water, for group B (positive serology) were $69.2 \pm 7.4 \mathrm{~cm}$ of water, for group C (cardiac form) were $95.8 \pm$ $5.1 \mathrm{~cm}$ of water, and for group D (digestive form) were $82.0 \pm 8,4 \mathrm{~cm}$ of water. Means and standard deviations of urethral closing pressure following parassympathomimetic injection were respectively: for group $\mathrm{A}=66.0 \pm 6.6 \mathrm{~cm}$ of water, for group $\mathrm{B}=$ $77.0 \pm 7.6 \mathrm{~cm}$ of water, for group $\mathrm{C}=98.3 \pm 8.8 \mathrm{~cm}$ of water, and for group $\mathrm{D}=45.9 \pm 6.2 \mathrm{~cm}$ of water. Kruskal-Wallis test comparing the averages and standard deviations of urethral closing pressure before bethanechol chloride for groups A, B, C and $D$ revealed $p>0.05$, whose interpretation shows that there is not a significance level. The same test after bethanechol chloride, comparing the averages and standard deviations through Wilcoxon test between groups $\mathrm{A}, \mathrm{B}$ and $\mathrm{C}$ also showed $\mathrm{p}>0.05$ and, thus, was not significant. Comparison of data of group D through Wilcoxon test showed a value of $p=0.003$, considered very significant. 
MODULATION OF URETHRAL ALPHA-SYMPATHETIC

Table 1 - Values of maximum urethral pressure in $\mathrm{cm}$ of $\mathrm{H}_{2} \mathrm{O}$ before and following subcutaneous administration of bethanechol chloride in patients from groups $A, B, C$ and $D$, as well as their respective means and standard deviations (SD).

\begin{tabular}{|c|c|c|c|c|c|c|c|c|c|c|c|c|c|c|c|}
\hline & & & & & vidua & Press & Valu & & & & & & & Mean & SD \\
\hline \multirow{8}{*}{ 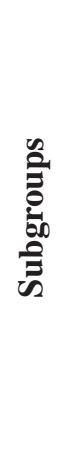 } & \multirow{2}{*}{ A } & Pre & 68 & 88 & 46 & 75 & 47 & 80 & - & - & - & - & - & 67.3 & 67.3 \\
\hline & & Post & 75 & 75 & 45 & 80 & 45 & 76 & - & - & - & - & - & 66.0 & 66.0 \\
\hline & \multirow{2}{*}{ B } & Pre & 50 & 63 & 75 & 98 & 60 & - & - & - & - & - & - & 69.2 & 69.2 \\
\hline & & Post & 85 & 60 & 80 & 100 & 60 & - & - & - & - & - & - & 77.0 & 77.0 \\
\hline & \multirow{2}{*}{$\mathrm{C}$} & Pre & 110 & 95 & 80 & 105 & 85 & 95 & - & - & - & - & - & 95.0 & 95.0 \\
\hline & & Post & 115 & 120 & 60 & 70 & 90 & 100 & - & - & - & - & - & 92.5 & 92.5 \\
\hline & \multirow{2}{*}{ D } & Pre & 70 & 70 & 130 & 69 & 136 & 48 & 80 & 66 & 68 & 65 & 100 & 82.0 & 82.0 \\
\hline & & Post & 39 & 233 & 45 & - & 88 & 52 & 25 & 57 & 30 & 54 & 23 & 43.6 & 43.6 \\
\hline
\end{tabular}

\section{DISCUSSION}

Maximum urethral closure pressure in patients with Chagas' disease in its cardiac and digestive forms showed to be higher than in control patients, though a significance level on Kruskal-Wallis statistical test did not occur. This fact conforms to previous descriptions that the urethral closure pressure in patients with Chagas' disease with digestive and vesical impairment was significantly increased (5). The fact that it was not significant in this study may be related to the lower number of patients. However, it is difficult to state that this fact is due uniquely to one factor, including here factors inherent to the methodology employed. Maximum urethral closure pressure following bethanechol chloride did not present significant alterations between groups A, B and $\mathrm{C}$, being in accordance to the drug's action which is parasympathomimetic, when in the urethra there is a predominance of alpha-sympathetic receptors. In the other hand, after bethanechol chloride injection the maximum urethral closure pressure in group D showed a significant drop, when a comparison with pressure values in this group before drug injection is made by the Wilcoxon test. The urethral contraction depends on adrenergic stimulation of alpha-1 receptors. Its relaxation is related to muscarinic receptors. Intrathecal or intraventricular injection of atropine sulfate or atropine methonitrate inhibit relaxation of urethral muscle during the voiding phase through stimulation of pelvic nerve. This fact suggests that stimulation of central muscarinic receptors promotes urethral relaxation during voiding (10). Muscarinic receptors in urethra also present inhibition of muscular contraction. Parasympathetic stimulation causes release of nitric oxide, produced by NO synthase (NOS) in cholinergic nerves, which promotes muscular relaxation in urethra (11). NOS blockage produces inhibition of urethral relaxation (6). Thus, destruction of parasympathetic system neurons, related to the lower urinary tract (3), caused by Chagas' disease, may lead to decreased release of NO, through reduction of cholinergic stimulus of muscarinic receptors at the urethral level, facilitating contraction. Bethanechol chloride produces cholinergic stimulus when injected subcutaneously. In patients with Chagas' disease with vesical hyporeflexia, a decrease in vesical capacity and in detrusor's contraction time was verified following injection of $5 \mathrm{mg}$, indicating parasympathomimetic activity. In the same way, the stimulation of muscarinic receptors in the urethra could promote release of NO and consequently cause relaxation of the sphincter.

This finding may suggest that the reduction of the neuropharmacological agent by parasympathetic denervation, which occurs in this disease, can exacerbate the action of the other neuromediator (alpha-sympathetic), as occurs in other organs, conse- 
quently raising the maximum urethral closure pressure. Thus, the bethanechol chloride injection, by stimulating muscarinic receptors, has promoted a decrease in maximum urethral closure pressure.

In this way, normally there would be a balance between sympathetic and parasympathetic functions in lower urinary tract and the specific parasympathetic lesion has caused an imbalance. This hypothesis formulated like this in relation to human beings cannot be found in literature, perhaps because there was not an experimental model which promoted a parasympathetic denervation as selective as that which occurs in Chagas' disease.

\section{CONCLUSIONS}

Chagas' disease in its intestinal form seems to alter urethral function as well. Parasympathetic stimulation acted so to decreased urethral pressure, indicating potential modulation by parasympathetic system over sympathetic system.

\section{REFERÊNCIAS}

1. Koberle F: Pathogenesis of Chagas disease. VER. Goiânia Méd. 1957; 3: 155 [in Portuguese].

2. Koberle F: Pathogenesis of Brazilian and European Megaesophagus. Thesis. Medical School of Ribeirão Preto, State University of São Paulo (USP), 1962 [in Poruguese].
3. Ciconelli AJ: Quantitative Analysis of the Neurons from the Lower Hipogastric Plexus in Normal and Experimental Infected Rats. Thesis. Medical School of Ribeirão Preto, State University of São Paulo (USP), 1963 [in Poruguese].

4. Vizzard MA, Erdman SL, Forsterman U, de Groat WC: Differential distribution of nitric oxide syntase in neural pathways to the urogenital organs (urethra, pênis, urinary bladder) of the rat. Brain Res. 1994; 646: 279-91.

5. Fraser MO, Flood HD, de Groat WC: Urethral smooth muscle relaxation is mediated by nitric oxide (NO) released from parasympathetic postglanglionic neurons. J Urol. 1995; 153: 461A.

6. Okomura M, Correa Neto A: Pathogenesis of Chagas disease. VER. Goiânia Méd. 1982; 28: 77 [in Portuguese].

7. Rocha JN, Suaid HJ, Martins ACP, Cologna AJ, Tucci Jr S: Urodynamic evaluation of patients with Chagas disease. Acta Cir Bras. 2001; 16 (Sup 1): 7-8 [in Portuguese].

8. Brown M, Wickham JEA: The urethral pressure profile. Br J Urol. 1969; 41: 211.

9. Lowe PJ, Saunders GBA, Downie JW, Awad SA: Catheter withdrawing apparatus for clinical urethral pressure profile studies. J Urol. 1976; 116: 626.

10. Masuda H, TsujiiT, Azuma H, Oshima H: Role of a central muscarinic cholinergic pathway for relaxation of the proximal urethra during the voiding phase in rats. J Urol. 2001; 165: 999-1003.

11. Anderson KE: Neurotransmission and drug effects in urethral smooth muscle. Scand J Urol Nephrol. (Suppl) 2001; 207: 26-34.

Received: October 18, 2002

Accepted after revision: February 17, 2003

\author{
Correspondence address: \\ Dr. Haylton Jorge Suaid \\ Hospital das Clínicas, FMRP \\ Departamento de Cirurgia e Anatomia \\ Sala 934, $9^{\circ}$ andar \\ Ribeirão Preto, SP, 14048-900, Brasil \\ Fax: + 5515 633-0836
}

